\title{
The Impact of Compliance with Codes of Corporate Governance on Quality of Disclosure: Comparative Study between Palestine and Jordan
}

\author{
Naser-Abdelkareem ${ }^{1} \&$ Mohammed T. Abusharbeh ${ }^{1}$ \\ ${ }^{1}$ Faculty of Administrative and Financial Sciences, Arab American University, Jenin, Palestine \\ Correspondence: Naser-Abdelkareem, Faculty of Administrative and Financial Sciences, Arab American \\ University, Jenin, Palestine. Tel: 97-25-9990-611. E-mail: Naser.abdelkarim@aauj.edu
}

Received: July 3, 2016

Accepted: July 28, 2016

Online Published: August 25, 2016

doi:10.5539/ijef.v8n9p215

URL: http://dx.doi.org/10.5539/ijef.v8n9p215

\begin{abstract}
This study seeks to achieve two objectives; (1) to examine the degree of compliance with corporate governance requirements in Palestine and Jordan by listed firms, and (2) to investigate the impact of corporate governance on quality of disclosure for Palestinian and Jordanian listed firms. A sample of 15 Palestinian listed companies and 30 Jordanian listed companies that fully disclosed their financial data in year 2007 and 2014 was used. This research employs multiple regression model and one sample t-test in order to analyze data variables and to test the research hypotheses.The research reveals that there are no statistically significant differences between Jordan and Palestinian listed firms in applying the respective codes of corporate governance, but these two countries are relatively still modest in observing corporate governance rules. This study also concludes that boards of director's characteristics have no significant impact on quality of disclosure in Palestine and Jordan. This indicates that corporate governance practices didn't have any significant effect on quality of disclosurefor Palestinian and Jordanian listed firms.
\end{abstract}

Keywords: corporate governance, corporate disclosure, annual reports, and compliance

\section{Introduction}

Corporate governance is considered one of the effective instruments that encourage investment in stock markets. Therefore, capital markets need a lot of constituents in order to enhance their efficiencies, through the available of information for investors that represent the minimum level of disclosure requirements and quality of financial reports. Recently, it becomes an important topic in practices and academic literatures, in order to ensure a competitive position, rise of capital, sustainable development and to combat corruption.

Significantly, the importance of corporate governance has increased dramatically in 2002 when a series of events led to the bankruptcies of large U.S. companies and the loss of thousands of jobs. Therefore, the way of companies are governed determines their fate as well as that of the economy in general. The investors are attracted to those companies with good corporate governance principles such as transparency and independent directors, because according to Organization for Economic, Cooperation, and Development (2004), corporate governance emphasize on the control rights and related responsibilities among different stakeholders in the company, such as managers, stockholders, and creditors who are identifying the rules and procedures for making decisions on company's affairs. Moreover, it provides the structure which company objectives are sets, the means of achieving those objectives and controlling the financial activities which are reflected in the company financial reports. However, the deficiencies in corporate governance can have as consequences not only in financial scandals and corporate liquidations but also financial crises and economic instability.

In fact, corporate governance is often defined as the system by which companies are directed and controlled for the benefit of shareholders, or is accountability to providers of capital (OECD, 2004). Thus, better corporate governance practices allow companies to access stock markets on better terms and can maximize firm's market value. Further, it can reduce the scope of undertaking inefficiencies of companies' investments and boost their profits. Accordingly, developing or emerging markets seek to attract more foreign investments in order to raise their market share of international portfolio investment. Therefore, listed companies in these markets are gradually more concerned with good governance as they need to guarantee that foreign investors' rights are 
appreciated. On other hand, the interrelationship between corporate governance and good disclosure provides investors a solid understanding of how decisions are made that may impact on their investments. Furthermore, Investors who are confident about the company corporate governance practices are more likely to become shareholders.

The compliance of corporate governance in Jordan and Palestine were prepared in the view of the development of economy as whole, and in the line with Jordanian Securities Commission (JSC) and Palestinian Capital Market Authority (PCMA) to develop their capital markets and to regulate listed companies in their stock exchange markets. In the case of Palestine, the code of corporate governance was declared in 2009 by Palestinian Capital Market Authority. Meanwhile, corporate governance in Jordan can be categorized into six dimensions (a legislative framework and government oversight, a capital market, disclosure and accounting standards, transparency in privatization, effective supervision of the board of directors, preservation of property rights and protection of minority rights) as stated in Jordanian company law of 1997 and its mandates of 2002 (Shanikat \& Abbadi, 2011).

This research paper is aim to find out the impact of applying the rules and standards of corporate governance on quality of disclosure in Palestinian and Jordanian listed companies. Further, it improves the financial stability of listed companies and reinforces the confidence of investors in stock markets. Moreover, the constructed research model evaluates the corporate governance practices by comparing the code of corporate governance issued by OECD in 1999 with current practices in Jordan and Palestine. Thus, this research explores the reality of compliance with corporate governance practices in Jordan and Palestine.

This research contributes to the literature through explaining the effect of board characteristics on quality of disclosure. Therefore, it is one of the first comparative empirical studies that investigate the relationship between corporate governance and disclosure in Jordan and Palestine. Accordingly, this study ensures that transparency and information reporting are involved by corporate governance principles.

The reminder of this research is organized as follows. The next section explores the previous studies of governance and disclosure as literature review and formulates the research hypotheses. The third section describes the selection of sample, data variables and research methods. The fourth section analyzes the data variables and discussion the results. Moreover, the final part concludes the research.

\section{Literature Review}

This section describes the interrelated prior studies of corporate governance and disclosure quality as follows:

\subsection{Quality of Disclosure}

In fact, a different meaning of quality disclosure has been suggested in prior literature. For example, Diamond and Verrecchia (1991) defines quality disclosure as the accuracy of investors" beliefs about stock prices following the disclosure. Moreover, quality disclosure is defined as current and potential investors can read and interpret the information easily (Hopkins, 1996). Further, Botosan (2004) stated that the definition of quality should be based on well-supported frameworks elaborated by professional accounting bodies and standard setters because they reflect a generally accepted notion of quality disclosure.

International Accounting Standard Board (1989) identified quality of disclosure as; comparability, understandability, relevance, and reliability. It means that the user of financial statement must be able to compare the annual reports of a company through time or with other companies in order to evaluate their financial performance and changes in their financial positions. Furthermore, it states that information must be understandable by users who have reasonable knowledge of business and economic activities and accounting and a willingness to study the information with reasonable diligence. It also argues that information must be relevant by influence on the decisions of users by helping them evaluate past, present of future events or confirming, or correcting, their past evaluations. Finally, information quality must include reliability that refers to information provided to public must be free from martial errors and bias. Further, it can be depended upon by users to represent faithfully that which it either purports to represent or could reasonably be expected to represent.

However, the current study defines disclosure quality as the process of spreading information on the impact of financial activities and market value of corporations. It assumes that disclosure can be important part in the soundness of corporate governance that integrates transparency of company performance. This perspective is sometimes referred as concept of "governance - to -disclosure" as mentioned by Gupta (2008). Consequently, this study argues that the compliance with the corporate governance has strong positive relationship with disclosure quality. 


\subsection{Corporate Governance}

Initially, corporate governance has been introduced by a number of international institutions such as World Bank and OECD. Actually in 1999, The OECD was developed the corporate governance principles in order to support and develop the organization framework (OECD, 2004). These principles were adopted by 30 countries among private and public companies in financial markets in the aim of increasing the efficiency of national economy and reducing the financial crises. Therefore, corporate governance is basically focused on the adaptation of mechanisms that safeguard the interests of shareholders in order to ensure that their companies are under control. Therefore, modern corporations today are interested to comply with the principle of governance in order to achieve corporate success (Shleifer \& Vishny, 1997).

In fact, there were many previous studies that exploring the applying of corporate governance in worldwide. Buck (2003) discussed corporate governance in Russia from a historical perspective and the hostile attitude that is taken toward Western and outside investors. Meanwhile, Rezaee et al. (2003) stated that good corporate governance promotes relationships of accountability among the primary corporate participants and this may enhance corporate performance of corporations and maximize shareholders wealth.Clarke (2003) stated that the rights of shareholders are the critical issue in the concept of corporate governance. In this manner, OECD (2004) added that corporate governance should ensure that disclosure and transparency of corporation are probably established. This indicates that transparency and full information reporting should include the company financial and operational results, objectives and strategies, and ownership structure. It also argued that corporate governance should ensure the equitable treatment of all shareholders including independent and minority members. It means that all shareholders should have the same voting rights and they can obtain sufficient information about their share before purchasing transaction. Furthermore, King and Wen (2011) added that protecting the rights of shareholder increases the confident in companies. They argued that maintaining clear shareholder records and providing information on timely and regular basis, improve shareholder rights to vote and select the member of board of directors. Moreover, Lawrence and Marcus (2009) stated that the governance provisions recently mandated by the U.S. stock exchanges are less closely linked to firm operating performance than are those not so mandated.

In emerging markets as Abu Hamam M. (2009) studied the impact of applying the rules of corporate governance on accounting statements and quality of financial reports in Palestinian exchange market. He has used the analytical descriptive method through collecting the data by preparing a questionnaire distributed to (150) members of the board of directors and executive managers in the stock market in Palestine. He found that the application of corporate governance has contributed greatly in in enhancing the role of the accounting statement and the quality of financial reports. The study has also concerned the necessity of providing the required components for implementing corporate governance through establishing a professional and administrative structure based on the credibility of the board of directors and executive managers. Further, Abedalkarim and Ijbara (2011) investigated the corporate governance practices on Palestinian securities exchange firms. They provided evidence that the PSE listed firms do not comply satisfactorily with corporate governance best practices especially when it comes with board composition and independence. Further, they added that the non-compliance level in the area of transparency and disclosure was not as obvious. It concluded also that the non-compliance including the non-existent of enforceable code of corporate governance and the outdated company law that is still in effect in the Palestinian territories. However, Alhazaimeh et al. (2014) examined the relationship between corporate governance and ownership structure on voluntary disclosure, with a particular focus on variables affecting in voluntary disclosure of listed companies in the Amman Stock Exchange (ASE). They found that board activity, foreign ownership, and non-executive directors and block holder ownership to be significant in influencing voluntary disclosure. It also revealed that the voluntary disclosure in the annual reports does potentially affect the market capitalization. Similarly, Shanikatand Abbadi (2011) assessed the reality of corporate governance of non- financial listed companies in Jordan. They found that basic shareholder rights were honored in decision-making, except for large decisions such as major asset sales. Moreover, this study revealed although controllers sometimes took action and prohibited insider trading. Further, the role and rights of stakeholders in corporate governance were respected, and stakeholders had a number of legal protections, which were largely covered in Jordan's Company Law. Finally, they also found that disclosure and transparency were observed to a large extent and boards largely fulfilled their responsibilities. Moreover, Aboagye et al. (2012) investigated on relationship between corporate governance and disclosure practices of Ghanaian listed companies. Their study aimed to further increase the understanding of disclosure practices and interrelationship between governance and disclosure of firms in Ghanaian stock exchange. They used random effect panel regression to establish the relationship between governance and corporate disclosure of 20 listed stocks from 
period of 2003 to 2007. The result revealed that although there has been improvement of disclosures practices over the years, the level of disclosure is fair. The study also documented a significant positive relationship between accounting experts on the corporate governance and disclosures practices. Furthermore, Kukreja G. (2013) examined on the effect of new corporate governance codes on disclosures in Bahrain listed commercial banks. He determined the coverage of corporate disclosure's by all listed commercial banks in Bahrain Bourse and test their quality, before and after the Corporate Governance Code. His finding indicated that all banks' board have been found recognizing the increasing importance of good corporate governance practices, as an important ingredient in the creation of sustainable shareholder value and protecting the interest of all shareholders. The study also concluded that there occur effective and positive changes in corporate disclosures after the introduction of corporate governance code.

In developed markets, Aburaya R. (2012) empirically investigated the relationship between corporate governance and each of the quantity and the quality of corporate environmental disclosures in the UK. It used content analysis of a sample of UK companies' annual reports from the period of 2004 to 2007 to analyze the relationship between corporate environmental disclosure practices and their association with corporate governance mechanisms. The findings revealed that a significant association between environmental disclosure quantity and, to a lesser extent, environmental disclosure quality and most corporate governance mechanisms. Further, it found that corporate governance mechanisms are significant at some categorical levels of environmental disclosure.

As result, the previous literatures stated that corporate governance principles should ensure the company rules and the board's accountability are clearly mentioned in company law. This means that the ability of board of directors to fulfill some specific functions such as reviewing and monitoring all issues related to the company performance. Nevertheless, limited prior research has been conducted directly that examines the relationship between corporate governance practices and corporate disclosure, and still very few studies addressed such relationship in Jordan and Palestine. Furthermore, not all corporate governance principles have been investigated in previous literatures. Therefore, the main objective of this paper is to empirically examine the impact of corporate governance on disclosure quality of Jordanian and Palestinian listed companies.

\subsection{Research Hypotheses Development}

In order to conceptualize the objective of this research, corporate governance mechanisms are classified in to the following groups: (1) board characteristics include; board independence and boards meeting and minority interests. (2) Audit committee independence. (3) Corporate governance report. Therefore, the key advantage from using this procedure is to enforce management to act in the best interest of stockholders, which in turn might effect on quality of disclosure (Bhagat \& Bolton, 2008).

\subsubsection{Board Independence}

Fama and Jensen (1983) argued that higher proportion of independent nonexecutive directors increases board effectiveness in monitoring managerial opportunism and, consequently, increases voluntary disclosures. Moreover, Barako et al. (2006) stated that the existence of independent members in board of director's structure is the main factor that influence on disclosure decisions of corporation. However, empirical evidence on the relationship between board independence and disclosure quality is limited and debated. Hence, this research expectsand formulates such the relationship as follows:

$\mathrm{H}_{1}$ : There is statistically positive significant between the existence of board independence and quality of disclosure.

\subsubsection{Board Annualmeetings}

Persons (2006) argued that board meeting frequencies reflect the diligence and vigilance of the board in carrying their monitoring duties. Therefore, the number of meetings enhances the company performance and corporate success. Therefore, this study expects that the increases in number of board meeting tend to improve quality of disclosure. Accordingly, the following hypothesis is proposed:

$\mathrm{H}_{2}$ : There is statistically positive significant between the board annual meeting andquality of disclosure.

\subsubsection{Audit Committee}

Ho and Wong (2001) argued that the existence of audit committee independent reduces the agency problem in corporation and that enhancing the quality of financial reporting. As result, this study argues that the existence of Audit committee improves the quality of disclosure. Hence, this study formulates the following hypothesis:

$\mathrm{H}_{3}$ : There is statistically positive significant relationship between Audit committee and quality of disclosure. 


\subsubsection{Corporate Governance Report}

This research states that governance report must be included in annual report as a separated and highlighted part. Further, the company must disclose all information that related to governance includes: the name of board members and their positions, board meeting, minority interests, Audit committee and the number of board independence. Therefore, this study proves that the existence of governance report is enhancing the quality disclosure in public shareholding companies. Hence, the following hypothesis is proposed:

$\mathrm{H}_{4}$ : There is statistically positive significant relationship between governance report and quality of disclosure.

\section{Research Method}

\subsection{Sample Selection}

This study emphasizes annual reports provided by companies listed at Palestinian exchange market (PEX) and listed companies at Amman stock exchange (ASE). Moreover, the data also obtained through Jordanian securities commission (JSC) website and other data sources from Palestinian Capital Market Authority (PCMA). Furthermore, this study was applied on 30 listed companies from Amman stock exchange and 15 listed stocks at Palestinian exchange market. However, the financial listed companies are not included because of it has special disclosure requirements and financial activities. Further, other numbers of listed companies were also excluded from the sample due to their limited data availability. On the other hand, the selection of sample was in the period 2007 and 2014 due to the following reasons: (1) the year 2007 was chosen according to a year before governance principles simultaneously were applied in Jordan and Palestine. (2) The year 2014 was also chosen because the year 2014 annual reports are considered as the last resource of information available at the time of study for the entire sample of research.

\subsection{Variables Description}

\subsubsection{Dependent Variable}

Quality of disclosure index is computed as the percentage of quality score awarded to total score of all items within checklist for each company divided by the number of items in checklist (Marston and Shrives, 1991). We have included corporate disclosure as dependent variable and measured through the presence of each item in checklist is coded (1); meanwhile, the non-disclosure of an item is coded (0).

\subsubsection{Independent Variables}

There are several variables of corporate governance included as independent in research model. These include:

1) Board independence (BI), is defined as the degree to which board members are dependent on the current chief executive officer (CEO). Independent directors are outside or inside directors who are manager of the company directors (Rupley et al., 2011). This study measures board independence through coding (1) for independent members to indicate existence of board independence and (0) to indicate non-existence (Almsafir et al., 2014).

2) Board meeting (BM), is considered a measure of board of director's effectiveness by the number of meeting that held per year. This study measure board meeting through total number of board meeting per a year (Anderson, 2005).

3) Audit committee (AUD), is defined as the responsibility for overseeing the financial report process and ensuring the objectivity of external audit (Uzun et al., 2004). Audit committee data will be coded (1) to indicate existence of audit committee and (0) to indicate non-existence. (Ho \& Wong, 2001).

4) Governance report (GR),is defined as the existence of governance report as separated part in company annual report. The governance report data will be (1) to indicate existence of governance report in the context of company annual report and (0) otherwise.

\section{Research Findings and Discussion}

This research aims to examine the influence of corporate governance standards on quality of disclosure for listed companies in Palestine and Jordan. Further, it also examines the degree of compliance with corporate governance requirements in Palestine and Jordan. Thus, this section presents the descriptive statistics for research variables, one sample t-test, regression analysis, and discussion the results.

\subsection{Descriptive Statistics}

Descriptive statistics of secondary data including sample means and standard deviations.As shown in table1, disclosure quality index in Palestine has a mean value of 65\% in year 2007 and 93\% in 2014. It provides 
evidence that PEX companies reinforce their financial reporting and they have an opportunity to take maximum level of disclosure requirements. As well as, Jordanian listed stocks has a mean value of $67 \%$ in year 2007 and 96.5\% in 2014. This means that those companies are fully disclosed their financial reports and other non-financial data during the years of study.

Table 1. Disclosure index for Palestinian and Jordanian listed companies

\begin{tabular}{llccc}
\hline Disclosure index & Years & Observation & Mean & Std. Dev. \\
\hline PSE listed companies & 2007 & 15 & 0.651 & 0.0780 \\
& 2014 & & 0.928 & 0.0537 \\
ASE listed companies & 2007 & 30 & 0.669 & 0.0915 \\
& 2014 & & 0.967 & 0.0355 \\
\hline
\end{tabular}

Table 2 displays the corporate governance codes that have a mean value of $28 \%$ in year 2007. This low ratio provides evidence that governance practices in Palestine are relatively modest. However, the applying codes of governance in 2014 have a mean value of $49.3 \%$ with standard deviation of $13.9 \%$. This indicates that listed stocks in Palestinian exchange market are enhanced their regulation regarding the corporate governance principles. But, this ratio is still below the expected. As well as, the codes of corporate governance in Jordan have a mean value of 5.3\% in 2007 and 33\% in 2014. , which is too low compared with Palestinian listed stocks in the same year. Table 2 reveals that Palestinian and Jordanian listed companies have a low degree of compliance with corporate governance practices in year 2007 and year of 2014.

Table 2. Corporate governance index for ASE and PSE listed companies

\begin{tabular}{llccc}
\hline Governance index & Years & Observation & Mean & Std. Dev. \\
\hline PSE listed companies & 2007 & 15 & 0.280 & 0.10142 \\
& 2014 & & 0.493 & 0.13870 \\
ASE listed companies & 2007 & 30 & 0.053 & 0.12794 \\
& 2014 & & 0.333 & 0.19885 \\
\hline
\end{tabular}

Table 3 presents the compliance with corporate governance principles in Ammanstock market in year before applying the codes and year 2014.Board of independence has a mean value of $47 \%$ in both two years. This means that $47 \%$ of board of directors is independence and the rest is companies. Board meeting has a mean value of $93 \%$ in 2007 and $87 \%$ in 2014. It indicates that most of the listed companies have a periodicboard meeting. However, Audit committee and governance report have no exist in the context of board characteristics in year 2007 but these variables are reinforced by PEX in 2014.This result confirms that those companies are still not applying the codes of corporate governance very well.

Table 3. Applying the codes of corporate governance for PEX in 2007 and 2014

\begin{tabular}{lcccc}
\hline Variable & Years & Observation & Mean & Std. Dev. \\
\hline Board independence & 2007 & 15 & 0.47 & 0.516 \\
Board meeting & 2014 & & 0.47 & 0.516 \\
& 2007 & 15 & 0.93 & 0.258 \\
Audit committee & 2014 & & 0.87 & 0.352 \\
Governance report & 2007 & 15 & 0.00 & 0.00 \\
& 2014 & & 0.40 & 0.207 \\
& 2007 & 15 & 0.00 & 0.00 \\
& 2014 & & 0.73 & 0.458 \\
\hline
\end{tabular}

Table 4 shows the corporate governance practices in Jordan.Board independence has not shown in the context of board functions in year 2007 and 2014. Board meeting has mean value of 13\% in 2007 and deviated by $34.6 \%$. However, this ratio had increased to $87 \%$ in 2014 . Audit committee and governance report have mean value of $13 \%$ and $0 \%$ in 2007 respectively. But, these ratiosare trended to $40 \%$ in 2014. These results indicate that applying corporate governance had improved by ASE companies. But, it's not practiced very well. 
Table 4. Applying the codes of corporate governance for ASE in 2007 and 2014

\begin{tabular}{llccc}
\hline Variable & Years & Observation & Mean & Std. Dev. \\
\hline Board independence & 2007 & 30 & 0.00 & 0.00 \\
& 2014 & & 0.00 & 0.00 \\
Board meeting & 2007 & 30 & 0.13 & 0.346 \\
Audit committee & 2014 & & 0.87 & 0.046 \\
Governance report & 2007 & 30 & 0.13 & 0.346 \\
& 2014 & & 0.40 & 0.498 \\
& 2007 & 30 & 0.00 & 0.00 \\
& 2014 & & 0.40 & 0.498 \\
\hline
\end{tabular}

\subsection{Paired Sample T Test}

Table 5 Exhibits the applying codes of governance for Palestinian exchange market. The paired sample t-test shows that the significance level of 2 tailed is below $\alpha=5 \%$. It indicates that there is a statistically difference in mean between 2007 and 2014 of applying the codes of governance in PEX. This means that the Palestinian listed stocks are enhanced their regulations and followed the codes of corporate governance.

Table 5. Paired sample t-test in applying codes of governance for PEX in 2007 and 2014

\begin{tabular}{ccc}
\hline Mean Difference & $\mathrm{t}-$ value & Sig (2 tailed) \\
\hline-.2133 & -4.904 & 0.000 \\
\hline
\end{tabular}

Table 6 reveals the applying codes of governance for Jordanian listed stocks. The sample t-test indicates the significance level of 2 tailed is below $\alpha=5 \%$. This means that there is a statistically difference in mean between year 2007 and 2014 in applying governance for ASE. This concludes that Jordanian listed stocks are improved their regulations regarding to the standards of corporate governance.

Table 6. Paired sample t-test in applying codes of governance for ASE in 2007 and 2014

\begin{tabular}{ccc}
\hline Mean Difference & t- value & Sig (2 tailed $)$ \\
\hline-.2800 & -6.960 & 0.000 \\
\hline
\end{tabular}

\subsection{Multiple Regression Analysis}

In this research, we are used a multivariate analysis of regression model in order to find out the effect of governance principles on quality of disclosure for listed companies in Jordan and Palestine. Technically, regression analysis is well accepted and commonly used in construction research model. Accordingly, this study conceptualizes the model between disclosure and four codes of corporate governance through the following hypothesized model:

$$
Q D=f(B I, B M, A U D, G R)
$$

Hence, the casual relationship among research variables are formulated as follows:

$$
Q D i t=\beta 0+\beta 1(\text { BIit })+\beta 2(\text { BMit })+\beta 3(\text { AUDit })+\beta 4(\text { GRit })+\varepsilon i t
$$

Where,

QD: Quality of disclosure.

$\beta 0$ : $\quad$ Intercept or constant.

$\beta 1$ : Coefficient of board independence.

B2: Coefficient of board annual meeting.

B3: Coefficient Audit committee.

B4: Coefficient of governance report.

$\varepsilon$ : Residual or standard error.

Table 7 presents the impact of governance principles on disclosure quality in Amman stock market. The 
regression results reveal: Firstly, $R$ square $\left(\mathrm{R}^{2}\right)$ indicates that $13 \%$ variability in disclosure quality could be explained by board independent, annual meetings, audit committee and governance report. It means that research model not well fit. Furthermore, p-value is greater than significant level of 5\%. This means that all alternative coefficients are rejected in the case of Amman stock market. Finally, regression findings conclude that annual meeting of the board of directors had no significant effect on quality of disclosure at level of significance $5 \%$ as expected. It also reveals that the existence of Audit committee and governance report have no statistically significant effect on quality of disclosure. Respectively, the t-value is $6.9 \%$ and significance level is above $5 \%$. Therefore, the result concludes that corporate governance characteristics have no impact on quality of disclosure in Amman stock exchange.

Table 7. Multiple regression results (dependent variable: quality of disclosure)

\begin{tabular}{cccccc}
\hline Variables & Constant & BI & BM & AUD & GR \\
\hline$\beta$ & 0.933 & -- & 0.362 & 0.025 & 0.025 \\
& $(0.000)$ & $(--)$ & $(0.059)$ & $(0.946)$ & $(0.946)$ \\
t-value & 49.722 & -- & 1.972 & 0.069 & 0.069 \\
$\mathbf{R}^{2}$ & $\mathbf{0 . 1 3 0}$ & Adj. $\mathbf{R}^{2}$ & $\mathbf{0 . 0 3 1}$ & \\
F test & $\mathbf{1 . 3 0 0}$ & Sig. & $\mathbf{0 . 1 6 9}$ & & \\
\hline
\end{tabular}

Hint: board independence (BI) is excluded from regression analysis because of zero value for all listed stocks.

As shown in Table 7 the results of regression analysis could be formulated based on standardized beta coefficients and the research model can be applied as follows:

$$
D Q=0.933+0.362 B I+0.025 A U D+0.025 G R
$$

From the above model, the regression analysis can be shown the coefficient weights for each research variables. The results indicate that board meeting has no statistically significant effect on disclosure quality of Jordanian companies; the estimated coefficient $\left(\beta_{2}\right)$ is $36.2 \%$ and p-value less than level of significance $5 \%$. It also concludes that audit committee has no statistically significant impact on disclosure quality, the estimated coefficient $\left(\beta_{3}\right)$ is $2.5 \%$ and t-value is 0.069 less than the rule of thumb 1.96 , then p-value is less than level of significance 5\%. However, this result is conflicted with Ho and Wong (2001). Furthermore, the existence of governance report has no effect on disclosure quality; coefficient correlation $\left(\beta_{4}\right)$ is $36.2 \%$ and p-value less than level of significance $5 \%$.

Table 8 presents the impact of corporate governance codes on disclosure quality of Palestinian listed stocks. The results of regression analysis indicatethat $60.2 \%$ of variability in disclosure quality ( $R$ square) can explained by board independence, board meetings, audit committee, and governance report. This means that the research model is well fit. Table 8 concludes one important finding; the existence of audit committee has statistically significant impact on quality of disclosure.

Table 8. Multiple regression results (dependent variable: quality of disclosure)

\begin{tabular}{|c|c|c|c|c|c|}
\hline Variables & Constant & BI & $\mathbf{B M}$ & AUD & GR \\
\hline \multirow[t]{2}{*}{$\beta$} & 0.862 & -0.209 & 0.333 & 1.174 & -0.671 \\
\hline & $(0.000)$ & $(0.397)$ & $(0.182)$ & $(0.010)$ & $(0.107)$ \\
\hline T-value & 16.948 & -0.886 & 1.435 & 3.199 & -1.771 \\
\hline $\mathbf{R}^{2}$ & 0.602 & Adj. $R^{2}$ & 0.442 & & \\
\hline F test & 3.775 & Sig. & 0.04 & & \\
\hline
\end{tabular}

From Table 8, the research model could be formulated based on regression coefficients weights. Therefore, the model can be applied as follows:

$$
D Q=0.862-0.209 B I+0.333 B M+1.174 A U D-0.671 G R
$$

Based on the above formula, we can conclude that board independence has no statistically significant impact on disclosure quality of Palestinian listed stocks, the estimated coefficient is $-20.9 \%$ and level of significance is greater than $\alpha=5 \%$. This finding is contradicted with Almsafir et al., 2014). Moreover, board annual meeting also has no statistically significant effect on disclosure quality, the estimated coefficient is $33.3 \%$ and $t$-value is 
1.435 less than the rule of thumb 1.96, and significance of level is greater $\alpha=5 \%$. Furthermore, Audit committee has statistically significant impact on disclosure quality, the estimated coefficient is 1.174 and p-value is $1 \%$ less than significance of level 5\%. Therefore, the existence of audit committee in the context of board characteristics has positively impact on quality of disclosure for Palestinian listed stocks. Thus, this result is consistent with Ho and Wong (2001). In addition, governance report has no statistically effect on disclosure quality. The estimated coefficient is $67.1 \%$ and $\mathrm{t}$-value 1.1771 is less than 1.96 and significance level is $10.7 \%$ greater than $\alpha=5 \%$.

As result, Table 9 can summary the hypotheses testing results as follows:

Table 9. Quality of disclosure hypotheses testing results

\begin{tabular}{ccccccc}
\hline \multirow{2}{*}{ Hypothesis } & \multicolumn{3}{c}{ Amman Stock Exchange (ASE) } & \multicolumn{3}{c}{ PalestineExchange (PEX) } \\
\cline { 2 - 7 } & $\begin{array}{c}\text { Directional } \\
\text { relation }\end{array}$ & $\begin{array}{c}\text { Alternative } \\
\text { hypothesis }\end{array}$ & Significant level & $\begin{array}{c}\text { Directional } \\
\text { relation }\end{array}$ & $\begin{array}{c}\text { Alternative } \\
\text { hypothesis }\end{array}$ & $\begin{array}{c}\text { Significant } \\
\text { level }\end{array}$ \\
\hline H1 & -- & Rejected & $5 \%$ & - & Rejected & $5 \%$ \\
H2 & + & Rejected & $5 \%$ & + & Rejected & $5 \%$ \\
H3 & + & Rejected & $5 \%$ & + & Accepted & $5 \%$ \\
H4 & + & Rejected & $5 \%$ & + & Rejected & $5 \%$ \\
\hline
\end{tabular}

\section{Conclusion}

The relationship between corporate governance principles and disclosure has been examined extensively in developed countries; but little attention has been giving to studying this issue in developing countries. Therefore, this research aims to shed light on the impact of governance principles on discourse quality in Jordanian and Palestinian listed companies. In particular, this study focuses on board independence, annual board meeting, and audit committee and governance report as independent variables, while quality of disclosurereflects the dependent variable. The research also used 15 listed stocks from Palestinian exchange market (PEX) and 30 listed stocks from Amman stock market (ASE) as sample of study.

This research also investigates the degree of compliance with corporate governance practices in Jordan and Palestine. The result indicates that there are no differences between Jordan and Palestine in the compliance with corporate governance. The two countries have relatively reinforced their regulations toward corporate governance practices. But, these levels of compliance with corporate governance are still below the expected.The research concludes that board independence does not exist in case of Jordanian public shareholding companies and Palestinian case. It also provides evidence that annual board meetings and governance report don't have any significant impact on quality of disclosure in both two countries. The main result of this research indicates that quality of disclosure didn'tinvolve by developing corporate governance practices in Jordan and Palestine. The results confirmed that board had extensively covered board function such as annual general meeting and the audited financial statements didn't reviewed by audit committee in annual board meeting. This research concludes that annual reports offer full quality of disclosure and transparency, but there are no comprehensive rules for corporate governance disclosure in Palestine and Jordan.

Finally, the effectiveness of enhanced disclosure quality and transparency depends on the entire system that used in both two countries as well as in any country. Therefore, to understand the efficiency of disclosure quality properlyfirstly, we need to evaluate the entire system of corporate governance.

\section{References}

Abedlkarim, N., \& Ijbara, K. (2011). Evidence of corporate governance compliance by Palestinian securities exchange listed firms. Global Journal of Business Research, 4(3).

Aboagye, F., Bedi, I., \& Kwakye, T. (2012). Corporate governance and disclosure practices of Ghanaian listed companies. Journal of Accounting in Emerging Economics, 2(2), 140-161. http://dx.doi.org/10.1108/20421161211229817

Abu Hamam, M. (2009). The effect of applying the corporate governance principles on quality of accounting statements: Empirical study on listed companies in PEX. Thesis, Islamic university - Gaza, Palestine.

Aburaya, R. (2012). The relationship between corporate governance and environmental disclosures: Uk evidence. Durham Thesis, Durham University. Retrieved from http://etheses.dur.ac.uk/3456/1/PhD_Thesis.pdf 
Al-Habaybah. (2009). Factors influencing the extent of mandatory compliance with IAS disclosure requirements by manufacturing companies listed at Amman Stock Exchange. Unpublished dissertation, the Arab academy for banking and financial sciences, Amman, Jordan.

Al-Haddad, W. M., Alzurqan, S. T., \& Al-Sufy, F. J. (2011). The effect of corporate governance on the performance of Jordanian industrial companies: An empirical study on Amman Stock Exchange. International Journal of Business and Social Science, 2(9), 55-69.

Alhazaimeh, A., Palaniappan, R., \& Almsafir, M. (2014). The Impact of Corporate Governance and Ownership Structure on Voluntary Disclosure in Annual Reports among Listed Jordanian companies. Procedia - Social and Behavioral Sciences, 129, 341-348. http://dx.doi.org/10.1016/j.sbspro.2014.03.686

Barako, D. G., Hancock, P., \& Izan, H. Y. (2006). Factors Influencing Voluntary Corporate Disclosure by Kenyan Companies. Corporate Governance, 14(2), 107-125. http://dx.doi.org/10.1111/j.1467-8683.2006.00491.x

Bhagat, S., \& Bolton, B. (2008). Corporate governance and firm performance. Journal of Corporate Finance, 14(3), 257-273. http://dx.doi.org/10.1016/j.jcorpfin.2008.03.006

Botosan, C. A. (2004). Discussion of a framework for the analysis of firm risk communication. The International Journal of Accounting, 39(3), 289-295. http://dx.doi.org/10.1016/j.intacc.2004.06.007

Buck, T. (2003). Modern Russian corporate governance: Convergent forces or product of Russia's history. Journal of World Business, 38(4), 299-313. http://dx.doi.org/10.1016/j.jwb.2003.08.017

Clarke, D. C. (2003). Corporate governance in China: An overview. China Economic Review, 14, 494-507. http://dx.doi.org/10.1016/j.chieco.2003.09.019

Diamond, D., \& Verrecchia, R. (1991). Disclosure, Liquidity, and the Cost of Capital. The Journal of Finance, 66, 1325-1355. http://dx.doi.org/10.1111/j.1540-6261.1991.tb04620.x

Fama, E., \& Jensen, M. (1983). Separation of ownership and control. The Journal of Law and Economics, 26(2), 301-326. http://dx.doi.org/10.1086/467037

Gupta. (2008). Transparency under Scrutiny: Information Disclosure in Global Environmental Governance. Global Environmental Politics, 8(2), 1-7. http://dx.doi.org/10.1162/glep.2008.8.2.1

Ho, S., \& Wong, K. S. (2001). A study of the relationship between corporate governance structures and the extent of voluntary disclosure. Journal of International Accounting, Auditing and Taxation, 10(2), 139-156. http://dx.doi.org/10.1016/S1061-9518(01)00041-6

Hopkins, P. (1996). The effect of financial statement classification of hybrid financial instruments on financial analysts' stock price judgements. Journal of Accounting Research, 34, 33-50. http://dx.doi.org/10.2307/2491424

King, T. H. D., \& Wen, M. (2011). Shareholder governance, bondholder governance, and managerial risk-taking. Journal of Banking and Finance, 35(3), 512-531. http://dx.doi.org/10.1016/j.jbankfin.2010.07.011

Kukreja, G. (2013). Impact of New Corporate Governance Code on Disclosures: Evidences from Bahraini Listed Commercial Banks. Advances in Management \& Applied Economics, 3(3), 171-191.

Lawrence, D., \& Marcus, L. (2009). Corporate governance and firm operating performance. Review of Quantitative Finance and Accounting, 32(2), 129-144. http://dx.doi.org/10.1007/s11156-007-0082-3

Marston, C. L., \& Shrives, P. J. (1991). The use of disclosure indices in accounting research: A review article. British Accounting Review, 23(3), 195-210. http://dx.doi.org/10.1016/0890-8389(91)90080-L

OECD. (2004). The OECD Principles of Corporate Governance. Retrieved from http://www.oecd.org/publications/Pol_brief

Persons, O. S. (2006). Corporate Governance and Non-Financial Reporting Fraud. Journal of Business and Economic Studies, 12(1), 27-39.

Rezaee, R., Olibe, K. O., \& Minmier, G. (2003). Improving corporate governance: The role of audit committees. Managerial Auditing Journal, 18(6/7), 530-537. http://dx.doi.org/10.1108/02686900310482669

Rupley, K. H., Brown, D., \& Marshall, S. (2011). Multi-Stakeholder Governance: Impact On Environmental Disclosure. Working Paper, Portland State University, USA.

Shanikat, M., \& Abbadi, S. (2011). Assessment of Corporate Governance in Jordan: An Empirical Study. 
Australian of Accounting Business and Finance Journal, 5(3), 93-106.

Shleifer, I., \& Vishny, R. W. (1997). A Survey of Corporate Governance. The Journal of Finance, 52, 737-783. http://dx.doi.org/10.1111/j.1540-6261.1997.tb04820.x

Uzun, H., Szewczyk, S. H., \& Varma, R. (2004). Board Composition and Corporate Fraud. Financial Analysts Journal, 60(3), 33-43. http://dx.doi.org/10.2469/faj.v60.n3.2619

\section{Copyrights}

Copyright for this article is retained by the author(s), with first publication rights granted to the journal.

This is an open-access article distributed under the terms and conditions of the Creative Commons Attribution license (http://creativecommons.org/licenses/by/4.0/). 